\title{
Quaternary hinterland evolution of the active Banda Arc: Surface uplift and neotectonic deformation recorded by coral terraces at Kisar, Indonesia
}

\author{
Jonathan Major $^{\mathrm{a}, *}$, Ron Harris ${ }^{\mathrm{a}}$, Hong-Wei Chiang ${ }^{\mathrm{b}}$, Nicole Cox ${ }^{\mathrm{a}, \mathrm{d}}$, Chuan-Chou Shen ${ }^{\mathrm{b}}$, \\ Stephen T. Nelson ${ }^{a}$, Carolus Prasetyadi ${ }^{c}$, Arif Rianto ${ }^{c}$ \\ a Department of Geological Sciences, Brigham Young University, Provo, UT 84602, USA \\ ${ }^{\mathrm{b}}$ High-precision Mass Spectrometry and Environment Change Laboratory (HISPEC), Department of Geosciences, National Taiwan University, Taipei 106, Taiwan, ROC \\ ${ }^{\mathrm{c}}$ Fakultas Teknologi Mineral, Universitas Pembangunan Nasional, Yogyakarta, Indonesia \\ ${ }^{\mathrm{d}}$ School of Science, Information Technology \&' Engineering, University of Ballarat, Ballarat, Australia
}

\section{A R T I C L E I N F O}

Article history:

Received 8 July 2012

Received in revised form 6 April 2013

Accepted 15 April 2013

Available online 3 May 2013

\section{Keywords:}

Kisar

Banda Arc

Coral terraces

Arc-continent collision

Tridacna

U-series dating

\begin{abstract}
A B S T R A C T
Coral terrace surveys and U-series ages of coral yield a surface uplift rate of $\sim 0.5 \mathrm{~m} / \mathrm{ka}$ for Kisar Island, which is an emergent island in the hinterland of the active Banda arc-continent collision. Based on this rate, Kisar first emerged from the ocean as recently as $\sim 450 \mathrm{ka}$. These uplifted terraces are gently warped in a pattern of east-west striking folds. These folds are strike parallel to more developed thrust-related folds of similar wavelength imaged by a seismic reflection profile just offshore. This deformation shows that the emergence of Kisar is influenced by forearc closure along the south-dipping Kisar Thrust. However, the pinnacle shape of Kisar and the protrusion of its metamorphic rocks through the forearc basin sediments also suggest a component of extrusion along shear zones or active doming.

Coral encrusts the island coast in many locations over $100 \mathrm{~m}$ above sea level. Terrace morphology and coral ages are best explained by recognizing major surfaces as mostly growth terraces and minor terraces as mostly erosional into older terraces. All reliable and referable coral U-series ages determined by MCICP-MS correlate with marine isotope stage (MIS) 5e (118-128 ka). The only unaltered coral samples are found below $6 \mathrm{~m}$ elevation; however an unaltered Tridacna (giant clam) shell in growth position at $95 \mathrm{~m}$ elevation yields a U-series age of $195 \pm 31 \mathrm{ka}$, which corresponds to MIS 7. This age agrees with the bestfit uplift model for the island. Loose deposits of unaltered coral fragments found at elevations between 8 and $20 \mathrm{~m}$ yield $\mathrm{U}$-series ages of $<100$ years and may represent paleotsunami deposits from previously undocumented tectonic activity in the region.
\end{abstract}

(c) 2013 Elsevier Ltd. All rights reserved.

\section{Introduction}

Arc-continent collision is a fundamental process in the development of mountain belts and the accretion of continents (e.g. Brown and Huang, 2009). One of the major questions about these collisions is how strain is distributed and translated into uplift throughout the orogen. For example, in the active Banda arc-continent collision of Indonesia, uplift is attributed to both lithospheric-scale isostatic processes (slab breakoff) and crustalscale horizontal shortening processes. Large-scale uplift associated with slab breakoff is proposed due to a seismic gap and lack of volcanic activity (Sandiford, 2008). Localized uplift associated with crustal shortening is demonstrated in many parts of the Banda

* Corresponding author. Present address: Bureau of Economic Geology, Jackson School of Geosciences, The University of Texas at Austin, University Station, Box X, Austin, TX 78713-8924, USA. Tel.: +1 801376 2046; fax: +1 5124710140.

E-mail address: JMajor@mail.utexas.edu (J. Major).
Arc due to well-documented folds and thrusts (Carter et al., 1976; Harris et al., 2000; Harris, 1991) and the local association between uplift of synorogenic sediments, and coral terraces with active faults (Cox et al., 2006; Harris, 1991, 1992; Merritts et al., 1998).

Kisar Island off the northeast coast of Timor is a direct link between active crustal structures and uplift within the hinterland of the collision. Kisar is an anomaly within the collision zone because it emerges as a small, isolated, pinnacle-shaped island of metamorphic rocks in the middle of the forearc basin (Figs. 1 and 2). Early geophysical work (e.g. Karig et al., 1987) in the Timor region concluded that crustal shortening is concentrated between the outer arc high (i.e. the axis of Timor) and the Timor Trough. These studies also note there is no evidence for shortening between the outer arc and the volcanic arc, although some strain may be taken up on the Wetar Thrust, which is found north of the island of Wetar where the volcanic inner arc is thrust over the Banda Sea back arc 


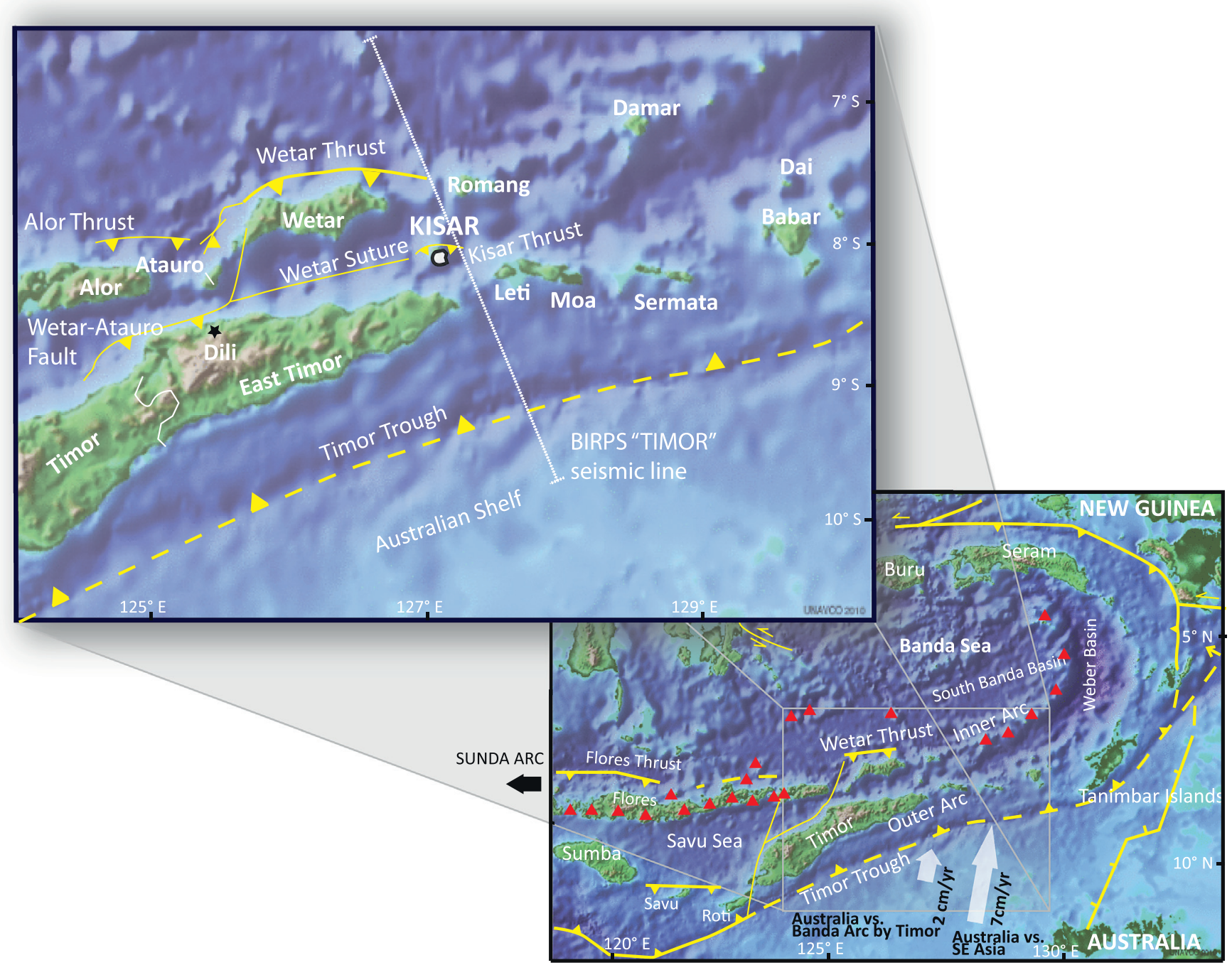

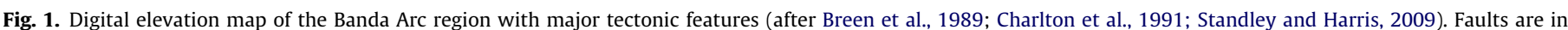

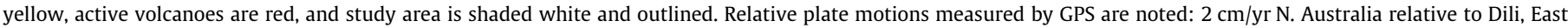

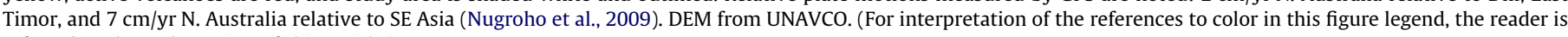
referred to the web version of this article.)

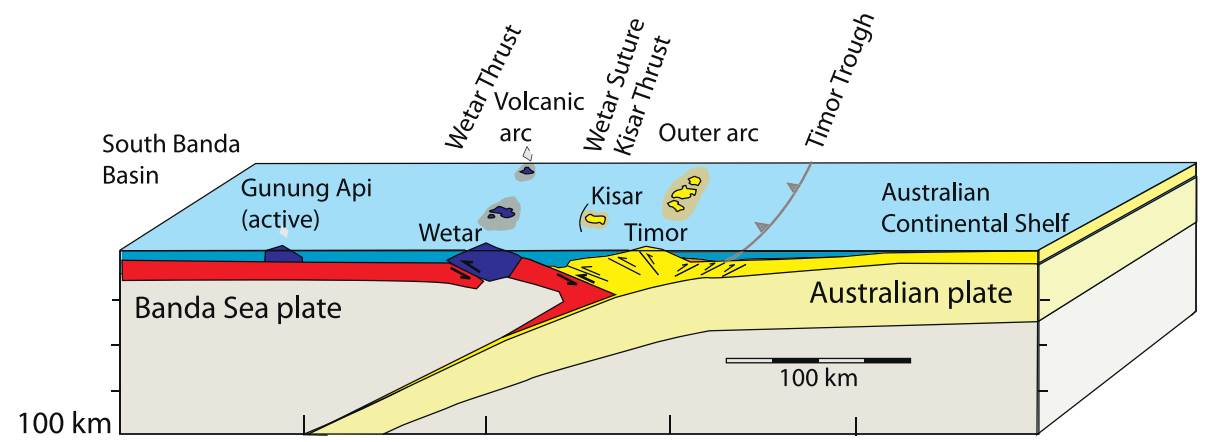

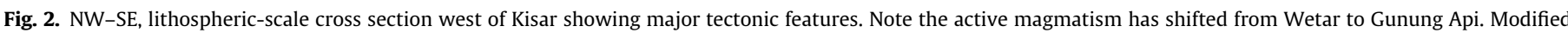
from Snyder et al. (1996).

basin. In contrast, models by Price and Audley-Charles (1987) speculate that most of the shortening is along the "Wetar Suture," which they propose is a south-dipping lithospheric-scale structure at the rear of the accretionary wedge just off the north shore of Timor. A thrust fault was discovered at this location by Breen et al.
(1989), but seismic images across the collision zone show no evidence of the whole lithosphere being involved.

More recent GPS measurements (Genrich et al., 1996; Nugroho et al., 2009) show $\sim 2 \mathrm{~cm} / \mathrm{yr}$ of strain is taken up within the collisional belt, which includes Kisar (Fig. 1). This shortening may also 
contribute to forearc closure as suggested by Price and AudleyCharles (1987).

Kisar Island rises in a pinnacle from near the "Wetar Suture". The coral terraces encrusted onto and surrounding the metamorphic rocks exposed in the island's interior provide a record of surface uplift since the island emerged from the sea. The purpose of this investigation is to examine Kisar Island, specifically its uplifted coral terraces, in order to determine the rate and spatial pattern of uplift, and use these data to test proposed uplift mechanisms for the hinterland region of the greater Banda orogenic system. Our study tests which processes are occurring and the relative contribution of each. These data are also crucial to assessing the earthquake and tsunami hazard potential in the region.

Methods employed to address these issues include: (1) geologic mapping, (2) surveying of the uplifted coral terraces that encircle the island, (3) U-series age analyses of coral samples in order to constrain the short-term surface-uplift rate of the island, and (4) new application and testing of the alpha counting method for Useries isotopes on Tridacna shells, which allow age estimates of older ( $>140 \mathrm{ka}$ ), high elevation terraces. Data from metamorphic rocks exposed in the core of the island are reported in a companion paper, which addresses the tectonic evolution and uplift of these rocks over the past $\sim 5 \mathrm{Ma}$.

\subsection{Geological setting and previous work}

\subsubsection{Kisar Island}

The southeastern Banda Arc of Indonesia is an ideal location to study active hinterland collisional processes because the numerous islands represent different stages of development in the actively evolving Banda arc-continent collision. Kisar, a small island northeast of Timor, is anomalously situated between the accretionary wedge of the non-volcanic outer Banda Arc and the volcanic inner Banda Arc. Kisar consists of metamorphic rocks capped by uplifted coral. The metamorphic rocks are incorporated into the orogenic wedge from the Australian lower plate (Harris, 2006). However, Kisar rises as an isolated uplift from 3 to $4 \mathrm{~km}$ depth $\sim 20 \mathrm{~km}$ north of the rear of the orogenic wedge, which is near the Wetar Suture. This suture separates the accreted Australian lower plate rocks from the Banda forearc, which is part of southeast Asia (Carter et al., 1976).

Dutch geologists described Kisar as early as the 1800s (Kuenen, 1942), but little geologic information has been published on the island. Kuenen (1942) recognized this enigmatic island's significance by stating that, "Kisar forms an important clue to the relations between the two [arcs]." Also, tentative links were made relating Kisar's rocks to Timor and Leti. Later studies show that the metamorphic rocks in Kisar are similar in composition (Richardson and Blundell, 1996) and protolith age (Harris, 2006) to the Aileu Complex on neighboring East Timor. The Aileu Complex is important because it is likely the most distal part of the Australian continental margin to enter the Banda Trench and displays the earliest evidence of collisional deformation and metamorphism (Harris, 2011).

Attempts to image the geometry of the arc-continent collision have led to several geophysical investigations (e.g. Breen et al., 1989; Jongsma et al., 1989; Karig et al., 1987; Masson et al., 1991; McBride and Karig, 1987; Snyder et al., 1996). Shallow seismic data was first interpreted to show Kisar as an uplifted block between strike-slip faults (Jongsma et al., 1989). Later, the British Institutions Reflection Profiling Syndicate (BIRPS) deep seismic reflection profile "Timor" imaged thrust faults and related folds along strike of Kisar (Snyder et al., 1996). From these data, Richardson and Blundell (1996) attribute the island to an out-of-sequence thrust.
Kisar is also correlated with the outer arc islands of Leti and Sermata to the east, where high-pressure metamorphic rocks are found (Ishikawa et al., 2007; Kadarusman et al., 2010; Kaneko et al., 2007). Uplifted coral terrace elevations along orogenic strike are used in these studies to infer a regional uplift pattern with the greatest total uplift in central Timor and decreasing amounts of uplift to the west and east. However, there are no studies of the age of coral terraces or metamorphic rocks of any of these islands.

\subsubsection{Regional geology}

Uplifted coral terraces are key to understanding the timing, pattern, and distribution of Quaternary deformation in the Banda Arc, because terraces provide multiple paleo-horizontal surfaces to track deformation through time. Previous geodynamic studies in eastern Indonesia use uplifted coral to constrain surface uplift rates of Timor, Sumba, Savu, Alor, and Roti (Fig. 1) (Bard et al., 1996; Chappell and Veeh, 1978; Hantoro et al., 1994; Merritts et al., 1998; Pirazzoli et al., 1991, 1993; Vita-Finzi and Hidayat, 1991). Other studies have quantified uplift using micropaleontology (Audley-Charles, 1986; De Smet et al., 1989; Fortuin and de Smet, 1991; Roosmawati and Harris, 2009; Scotney et al., 2005), and geochronology (Harris, 1991, 2011; Harris et al., 2000). No uplift or survey data exist for the minor islands east of Timor (i.e. Kisar, Leti, Moa, Sermata, Babar) except for one study in the Tanimbar Islands (De Smet et al., 1989). These islands between Timor and Tanimbar represent a $400 \mathrm{~km}$ long section of young arc-continent collision for which little geologic data exists. Collision between the northern Australian margin and the Banda Arc initiated at central Timor and propagated eastward and westward along orogenic strike (Harris, 1991), so the smaller outer Banda Arc islands to the east and west represent progressively younger stages of the collision, therefore more recent emergence to sea level, and where more coral terraces are preserved.

\section{Coral terrace surveys}

\subsection{Methods}

One of the most revealing ways to track Quaternary deformation in the Kisar region is by surveying and correlating coral terraces to test for warping, which is reveals the pattern of active deformation. Terrace profiles were gathered using handheld GPS units with built-in barometric altimeters (Garmin GPSMap 60CSx, Garmin ETrex, and Garmin GPSMap 76CSx). Profile locations were chosen close to accessible beaches so altimeters could be calibrated before and after each survey. The altimeters were zeroed at the recognizable high tide mark, which is observed approximately $1 \mathrm{~m}$ above mean sea level. Most profiles were measured in less than $2 \mathrm{~h}$ in order to minimize error due to barometric fluctuations, and they were taken roughly perpendicular to the coast. Two GPS units were used and compared for accuracy for nearly all profiles and discrepancies were rarely more than 1$2 \mathrm{~m}$. A composite of terrace elevations is constructed by grouping elevation data and examining the profiles to identify trends and similarities (Table 1 and Appendix).

The width of the uplifted terraces is defined by the distance between the inner and outer edges. The inner edges of the profile, especially at low elevation, often preserve the original wave-cut notch providing a suitable datum. At higher elevations, where preservation is generally poorer, the terrace inner edges is instead marked where slopes increased noticeably. Terrace outer edges are generally less well-defined due to partial erosion by subsequent sea-level highstands, which means terrace widths are a minimum estimate of the original width. The outer edges of the terraces are marked at ledges or cliffs along the path of the profile. Outer and 
Table 1

More complete data found in Appendix.

\begin{tabular}{|c|c|c|c|c|c|c|}
\hline Terrace & $\begin{array}{l}\text { Inner edge } \\
\text { elevation (m) }\end{array}$ & $\begin{array}{l}\text { Outer edge } \\
\text { elevation }(\mathrm{m})\end{array}$ & Width & $\begin{array}{l}\text { Number of terrace } \\
\text { profiles where } \\
\text { observed }\end{array}$ & Coasts where found & Notes \\
\hline Ia & $5-6$ & 3-5 (usually eroded) & Up to $10 \mathrm{~m}$ & 5 & ALL & Minor terrace \\
\hline $\mathrm{Ib}$ & $9-11$ & $8-12$ (often eroded) & Up to $10 \mathrm{~m}$ & 6 & ALL & Minor terrace \\
\hline II & $17-22$ & $14-18 \mathrm{~m}$ & Up to $1 / 2 \mathrm{~km}$ & 14 & ALL & Major terrace, warped \\
\hline IIa & $27-33$ & $19-24 \mathrm{~m}$ & 10 's of $\mathrm{m}$ & 6 & $\mathrm{~N}, \mathrm{~W}, \mathrm{E}$ & Minor terrace \\
\hline IIb & $40-42$ & $29-38 \mathrm{~m}$ & $\sim 100 \mathrm{~m}$ & 4 & $\mathrm{~N}, \mathrm{~W}$ & Large minor terrace \\
\hline IIc & $45-48$ & $40-41 \mathrm{~m}$ & 10 's of $\mathrm{m}$ & 3 & $\mathrm{~N}, \mathrm{~S}, \mathrm{E}$ & Minor terrace \\
\hline III (near antiforms) & $61-64$ & $52-58 \mathrm{~m}$ & $200-300 \mathrm{~m}$ & 3 & $\mathrm{~N}, \mathrm{~S}$ & Major terrace, 2 higher elevation group \\
\hline III (near synforms) & $66-72$ & $61-64 \mathrm{~m}$ & “، & 4 & $\mathrm{~W}$ & Major terrace, 2 lower elevation group \\
\hline IIIa & $77-78$ & $69-77 \mathrm{~m}$ & $\sim 100 \mathrm{~m}$ & 2 & $\mathrm{~N}, \mathrm{~W}$ & Minor terrace \\
\hline IV & $88-94$ & $79-86 \mathrm{~m}$ & $50-300 \mathrm{~m}$ & 4 & $\mathrm{~N}, \mathrm{E}, \mathrm{W}$ & Major terrace \\
\hline IVa & $98-100$ & Poorly defined & $<20 \mathrm{~m}$ & 1 & $\mathrm{~W}$ & Minor terrace \\
\hline $\mathrm{IVb}$ & $120-121$ & $100-101$ & 10 's of $\mathrm{m}$ & 1 & $\mathrm{~W}$ & Minor terrace \\
\hline $\mathrm{V}$ & $132-140$ & $122-135$ & Eroded & 1 & $\mathrm{~W}$ & Major terrace \\
\hline
\end{tabular}

inner edges are obvious for most locations at low elevation $(<60 \mathrm{~m})$, but are difficult to locate on the higher, older terraces. On the south coast of Kisar, coralline limestone is rarely found above terrace II and wave-cut terraces in the underlying metamorphic rock were marked instead.

\subsection{Description of terraces}

Multiple uplifted terraces of coralline limestone at various sizes encircle Kisar from sea level to approximately $145 \mathrm{~m}$ asl (Appendix, summarized in Table 1 ). The compilation of terrace survey data show at least 4 major and 8 minor recognizable terraces.

Modern reef - The modern fringing reef of Kisar Island ranges in width from a few hundred meters at Leti Bay to less than $50 \mathrm{~m}$ on the south coast (Fig. 3). Many species of coral flourish in the reef including Porites, which grows from a depth of $\sim 8 \mathrm{~m}$ to sea level. There are also many giant Tridacna clams. The modern reef slopes from near sea level to 3-5 me below sea level at the reef flat and is approximately 8-10 $\mathrm{m}$ deep at its outer edge. Below the outeredge drop-off, coral are sparse and a few small ledges can be seen underwater. Around most of the island, the modern reef abruptly ends at the shoreline in steep cliffs cut into fossil coral. A wavecut notch is prominent at the base of all cliffs, and along many sections of the coast multiple wave-cut notches are found above the modern reef (Fig. 4). These stacked, wave-cut notches may record co-seismic uplift from previously undocumented earthquake activity in the region.

Terrace I - A narrow, discontinuous terrace that is typically preserved only in embayments with minor wave erosion. The lowest terrace is found around $5 \mathrm{~m}$ and $10 \mathrm{~m}$ asl, which may indicate two discrete erosional events into the larger terrace II. Where the terraces are not found, it is sometimes represented by wave-cut notches incised into the rise of terrace II.

Terrace II - The most prominent terrace on the island is up to $0.5 \mathrm{~km}$ wide, sparsely vegetated, and laterally continuous. The relief from the outer to inner edge is less than $5 \mathrm{~m}$. Most of the terrace is found $>20 \mathrm{~m}$ asl. The surface is beveled smooth by erosion, but the dry climate has limited karstification. Coast-parallel surveys of terrace II indicate that it is gently warped into a series of east-west trending folds (Fig. 3). The total difference in elevation between the crest of the folds versus the troughs is only 3-6 m spread over a horizontal distance of up to $1 \mathrm{~km}$. Three additional minor terraces are found above terrace II in many locations (Fig. 6). The minor terrace IIb at $\sim 40 \mathrm{~m}$ is the largest subterrace on the island.

Terrace III - Also a very prominent terrace, but not as continuous or well-preserved as terrace II. Terrace III is observed on all coasts, but is difficult to recognize on several transects, which is likely due to erosion or more limited coral growth. Terrace III is beveled flat in most locations. Transect data show two populations of terrace III inner-edge elevations at $\sim 60 \mathrm{~m}$ and $\sim 70 \mathrm{~m}$. In general, the higher terrace III elevations correlates with the crests of antiforms identified on terrace II, and the lower ones with synforms. The greater magnitude of warping is consistent with its older age. At least 1 subterrace was noted above terrace III.

Terrace IV - This terrace is less prominent than the lower terraces and not recognized in all traverses. Terrace IV is found at an elevation of 80-90 m asl and absent on the south coast. At least 2 subterraces above terrace IV are recognized on the west coast of Kisar where the terraces are best preserved.

Terrace $\mathbf{V}$ - The highest elevation terrace on Kisar. It is only found on parts of the west and north coasts and is absent elsewhere, likely due to erosion. The terrace flat is around 130$140 \mathrm{~m}$ asl.

\subsection{Results}

The major terraces on Kisar are beveled flat and the minor terraces are primarily cut into the slopes between larger terraces. The lowest terraces form an imposing cliff along the coastline, with one or more wave-cut notches found in several locations (Fig. 4). Coralline limestone can be up to tens of meters thick encrusting the island's metamorphic rocks. The large, low elevation terraces (i.e. terrace II and III) can be traced continuously around the island (Fig. 3), but minor terraces and high elevation terraces (i.e. terrace IV and V) are not as laterally continuous or well-preserved. Terraces are less well-preserved on the south coast, where the active reef is also thin due to strong wave action. The terraces are sparsely vegetated with thin or no soil, occasionally fractured, and weather gray.

Most of the coral terraces are systematically warped. Crests and troughs of several folds on the east and west coasts can be correlated across the island. The crests and troughs are measured by surveying changes in elevation of well-preserved erosional surfaces between $10-25 \mathrm{~m}$ asl (Fig. 3). Terrace warping is measureable at the $\leqslant 2 \mathrm{~m}$ resolution of the GPS survey (Fig. 7). Measured elevation differences of 3-8 ms between the crests and troughs of the folds indicate gentle warping of terrace II (Fig. 7). This variation increases to a difference of up to $11 \mathrm{~m}$ on terrace III. Corresponding geomorphic trends (i.e. linear trends of hills, protrusions along the coastline; see Fig. 6 ) are also observed on aerial imagery along the trend of these folds (Fig. 3). One example of greater uplift near an antiformal crest is Muidau beach on the NW coast of Kisar. Shoreward of the beach is an eroded coral platform near sea level 


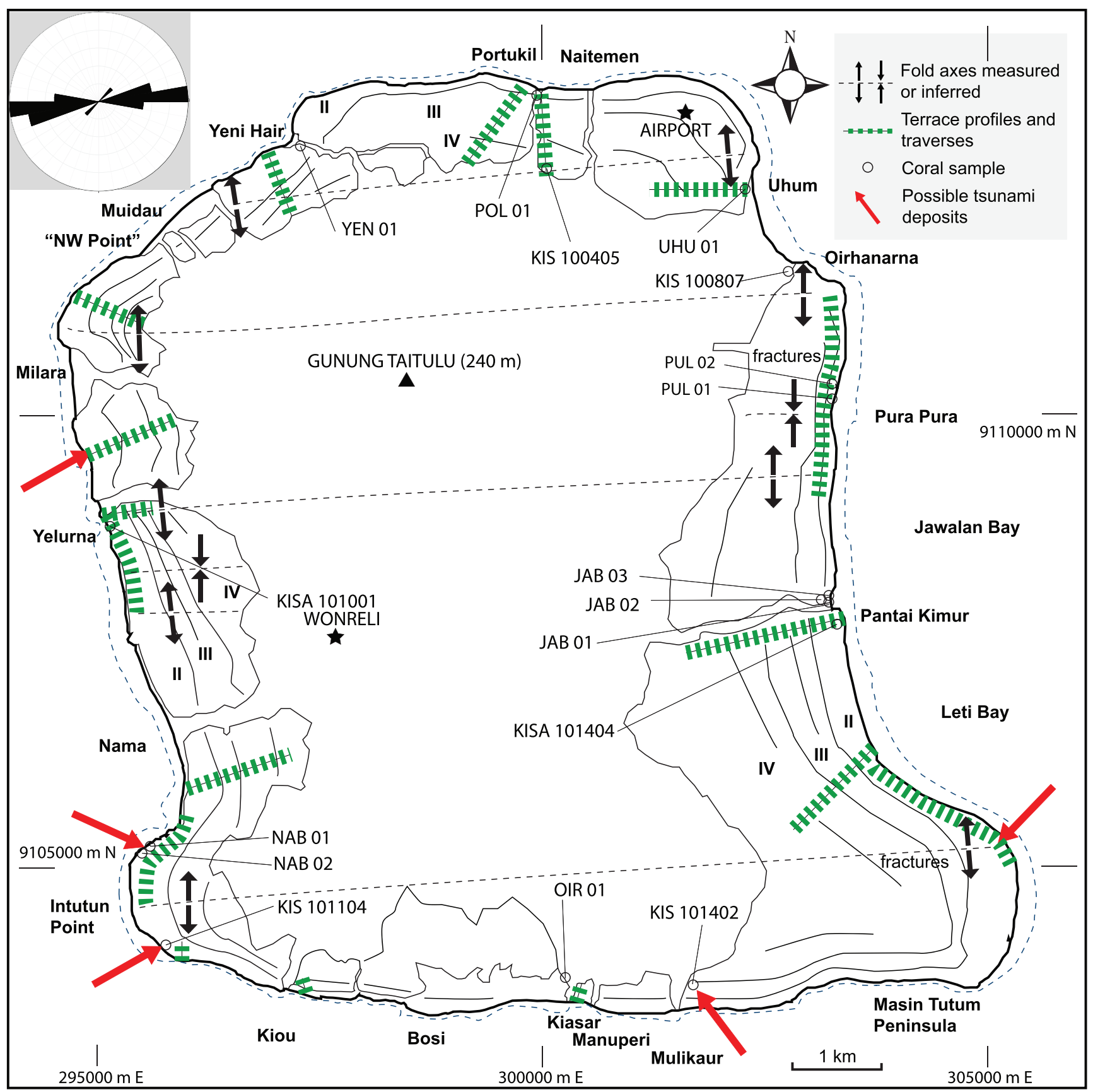

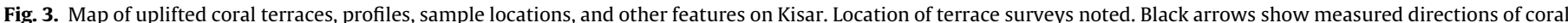

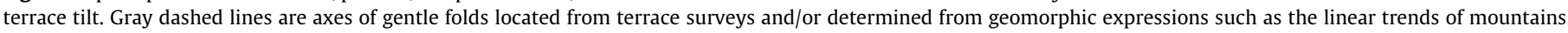

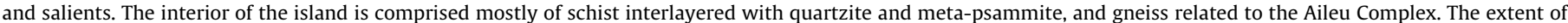

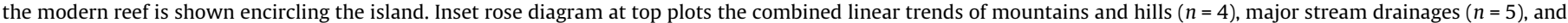
salients $(n=2)$, which are geomorphic evidence for active folding on the island.

that we interpret as a Holocene surface (Fig. 5). These geomorphic features, and multiple uplifted wave-cut notches above the current storm high-tide at several locations throughout the island, indicate that Kisar is actively deforming (Fig. 4).

\section{Geochronology}

We interpret the uplifted coral terraces as dominantly recording surface uplift (i.e. excluding erosion), not rock uplift or exhumation (terms after England and Molnar, 1990) due to the fact that the majority of the coral terraces have not been removed by erosion. Also, there is only a small amount of area where any rock could have been removed in the short time since the island first emerged above sea level. In other words, the exceptional preservation of the terraces supports the assumption that these are a measure of surface uplift for this island in the tectonically active Banda Arc, Total rock uplift (or uplift of rocks) with reference to the geoid is both a product of surface uplift and exhumation, the latter of which cannot be constrained by this study. As argued by England and Molnar (1990), surface uplift is the most useful displacement when discussing the tectonic forces at work in mountain belts. Surface uplift 


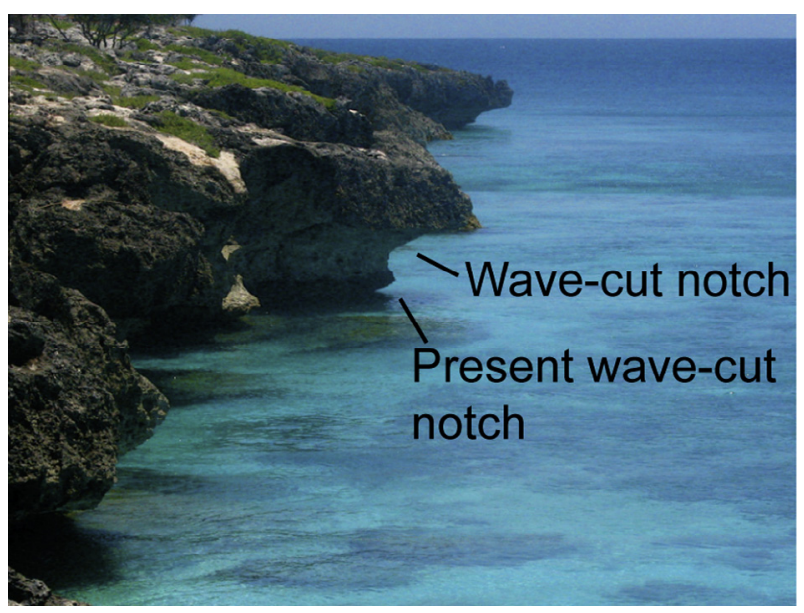

Fig. 4. Double wave-cut notches above the active reef on the coast of Kisar, which may be due to co-seismic uplift from undocumented earthquake activity in the region, are found in several locations on the island. We interpret these as indicating continued uplift of the island.

rates are typically estimated by surveying and determining ages of exposed coral terraces and matching terrace elevations with known elevations of Quaternary sea-level maxima. This approach assumes that the uplifted terraces originally represented sea-level highstands. Accounting for eustatic sea level changes allows mean sea level to serve as datum with which to compare the uplifted terraces. ${ }^{14} \mathrm{C}$ ages of Tridacna (giant clam) shells were used to measure the youngest uplifted coral terraces in West Timor (Vita-Finzi and Hidayat, 1991) and New Guinea (Chappell and Polach, 1972), but the short time scales $(<60,000$ years) achievable by the method limits its usefulness for studying older terraces. Most commonly, U-series age analysis is used for unaltered coral, which yields ages in Indonesia of up to $300 \mathrm{ka}$ (Pirazzoli et al., 1991, 1993). Also used, but less common, is electron spin resonance (ESR) dating, which can yield ages to at least $600 \mathrm{ka}$ (Pirazzoli et al., 1991, 1993).

Coral takes in uranium from sea water as it grows, so it is possible to obtain a radiometric age using the U/Th system (Edwards et al., 1987). However, one of the greatest limitations of this method is the difficulty in finding suitable samples, because the original aragonite of corals easily alters and recrystallizes to calcite. The assumption of closed-system behavior can only be made if coral remains nearly pure aragonite (Cheng et al., 2000; Edwards et al.,
2003). Our earlier studies of uplifted coral terraces throughout the Banda Arc (e.g. Cox, 2009; Merritts et al., 1998) demonstrate that unaltered coral are consistently found as old as $\sim 130 \mathrm{ka}$ (MIS 5e), but that suitable coral samples (>95\% aragonite) can still be elusive, especially older than MIS 5 e. Some species also prove more reliable, such as Porites, which we preferentially sampled. However, the most resistant species to alteration of the uplifted reefs on Kisar are the large Tridacna shells.

Tridacna shells are more dense and impermeable than coral and slower to recrystallize to calcite, and therefore provide the only suitable samples for ages of older (i.e. pre-MIS 5e) terraces. These mollusks are commonly found on coral terraces throughout the Banda Arc, including the north coast of Timor. On Kisar, no unaltered corals are found at elevations $>20 \mathrm{~m}$, but several Tridacna shells with minimal observed alteration are found in growth position on higher terraces. We sampled a large, unaltered Tridacna shell near the top of terrace IV at $95 \mathrm{~m}$ elevation. A few similar Tridacna shells were previously collected from uplifted terraces of neighboring Timor. The shells from Timor are associated with unaltered coral of known age and analyzed for this study to test of the reliability of ages obtained.

Previous attempts to obtain U-series ages from Tridacna shells using inductively coupled plasma mass spectrometry (ICP-MS) methods have been unsatisfactory, perhaps due in part to the small size scale of the sample analyzed. The erratic ages produced by this method show evidence of open-system behavior and variable uranium concentrations at the scale (tens of $\mathrm{mg}$ ) of the sample analyzed. Kaufman et al. (1971) made several arguments against the reliability of mollusks in general for U-series work, showing that the concentration of uranium increases after burial, and that ${ }^{230} \mathrm{Th} /{ }^{234} \mathrm{U}$ ratios often yield incorrect ages. Evidence for open-system behavior was cited for many of the 400 analyses reviewed by Kaufman et al. (1971). However, none of these analyses were on Tridacna shells, which are the largest mollusks. Omura et al. (1973) reported heterogeneous distribution of uranium between the outer and inner layers of a Tridacna crocea from the Ryukyu Islands. Data from a giant clam presented in Edwards et al. (2003) also shows that mollusks exclude uranium relative to coral and conclude that it is the major reason uranium-series work is difficult for mollusks. Nevertheless, motivated by the lack of suitable coral samples and the relative abundance of Tridacna shells in the region, we chose to test other methods for obtaining ages.

To address the issue of low and variable uranium concentrations throughout the shell, large enough samples were analyzed to homogenize the growth layering and obtain sufficient uranium

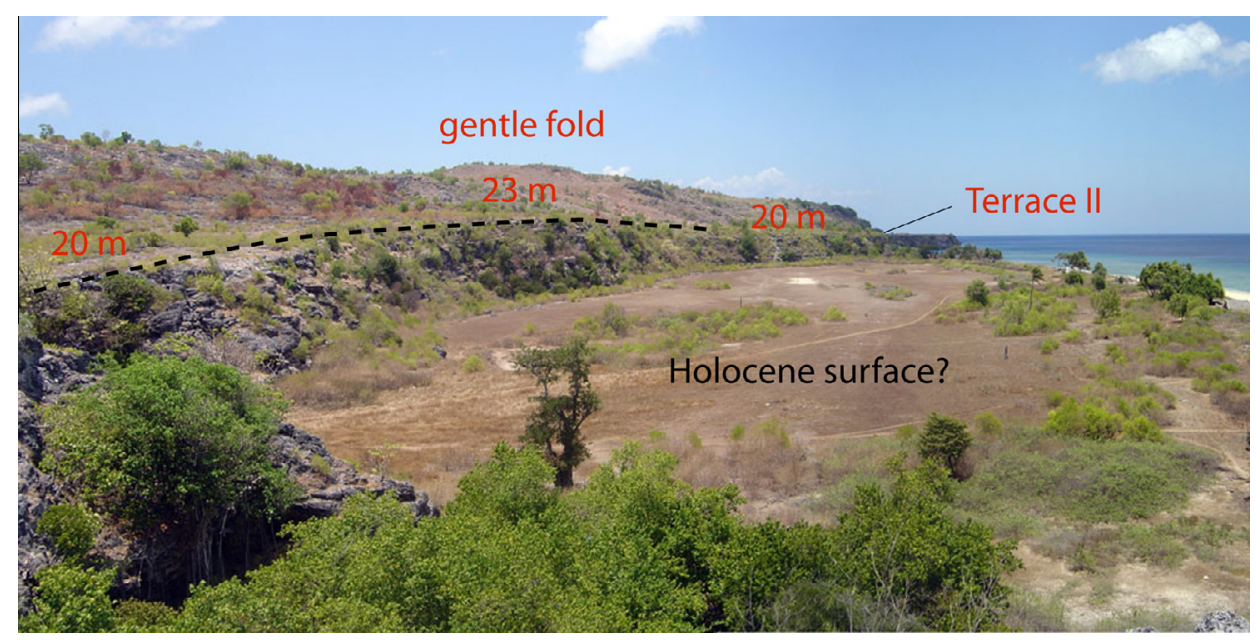

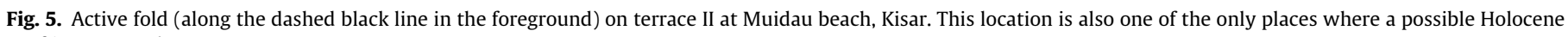
Reef is preserved. 


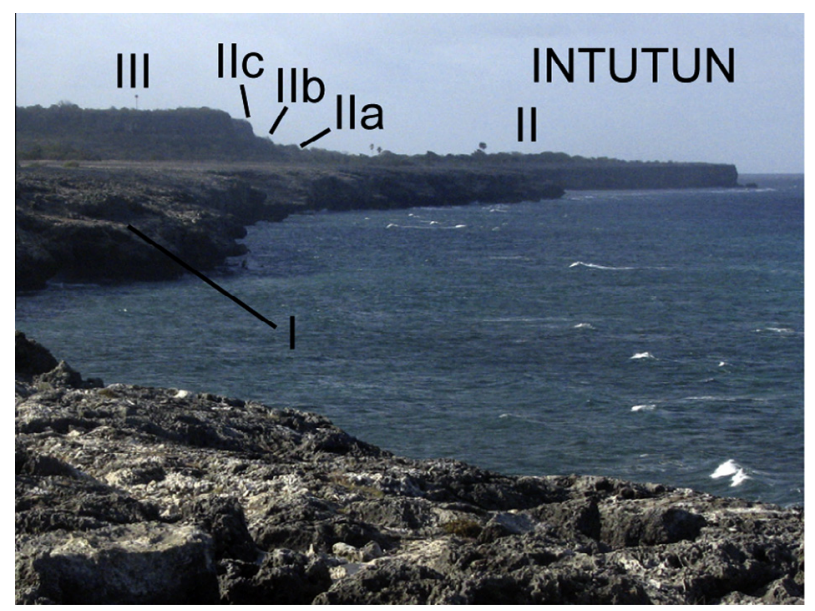

Fig. 6. Major and minor terraces of the west coast looking south at Intutun Point Terrace II is a few meters higher in the distance than the foreground. The coastline also protrudes oceanward at Intutun Point, and corresponds to a gentle antiform measured in one of the terrace surveys.

for alpha counting. Our samples included the bulk of the thickness of the shell, while avoiding the outermost surface layers. At this larger scale, we surmised that the shell is less likely to behave as an open system. Modern, conventional ICP-MS analysis uses only very small amounts of material, so we experimented with the alpha counting method, which is better suited for analyzing the large amount of material needed to homogenize the sample. One shell sample from Kisar was analyzed in which the exact age was unknown, but could be roughly estimated. Two Tridacna shells, one relatively young $(\sim 7 \mathrm{ka})$ and one older $(\sim 121 \mathrm{ka})$, were also analyzed from East Timor, where the age of the shells is well-constrained by reliable, conventional ICP-MS U-series ages of adjacent coral.

Although the resolution of the alpha counting method is lower than that obtained from conventional ICP-MS, it is sufficient in most cases to determine the major sea-level highstands associated with the growth of the shell. The alpha counting technique for Tridacna shells may be the only method for determining the age of older terraces with heavily altered coral found at high elevations.

\subsection{Analytical methods}

\subsubsection{U-series on coral using MC-ICP-MS}

Thirteen coral samples, out of nearly twenty collected from Kisar, were analyzed for U-series isotopic compositions by multi-collector inductively coupled plasma mass spectrometry (MC-ICP-MS) with the Thermo Electron Neptune at the High-precision Mass
Spectrometry and Environment Change Laboratory (HISPEC) at National Taiwan University. All samples were initially inspected visually for obvious signs of alteration, and then checked for sufficient aragonite content (>95\%) by X-ray diffraction analysis (XRD), which eliminated 5 out of 18 total samples. Chemical and instrumental analysis followed methods described in Shen et al. (2003, 2002, 2010). The unaltered samples were mostly found on the sides of small ravines recently cut through the terraces (Fig. 3). Unaltered samples were also found in fresh wave-cut cliffs on the coasts. Several loose, unaltered corals were also found scattered on top of much older and weathered terraces.

\subsubsection{U-series on shells by alpha counting}

Three samples of Tridacna shell ( 1 from Kisar and 2 from eastern Timor) were analyzed to test the alpha counting method needed for large samples. Several pieces from the interior of each Tridacna shell were cut and cleaned, carefully avoiding any signs of alteration. These large shell samples yielded homogenously colored, apparently unaltered aragonite for acid digestion. Aragonite content was previously checked by XRD for the pair of samples from Timor and found to be greater than 99\% aragonite (Cox, 2009). Approximately $50 \mathrm{~g}$ of aragonite per sample were calcined in a $1000{ }^{\circ} \mathrm{C}$ oven overnight. The mass of the sample was measured before and after calcination, then the sample was crushed with mortar and pestle and dissolved in concentrated $\mathrm{HCl}$. A measured solution of ${ }^{232} \mathrm{U}$ and ${ }^{228} \mathrm{Th}$ spike with known activities was added to the sample for isotope dilution. The sample and spike were rotated in a bottle overnight to equilibrate.

Column separations with ion exchange resins followed a procedure for carbonates from Bischoff and Fitzpatrick (1991) that was slightly modified to increase Th recovery. Separate U and Th columns were used. Dissolved metals ( $U$ and $T h$ ) form a micro-precipitate with $\mathrm{CeF}_{3}$, then the solutions containing $\mathrm{U}$ and Th-bearing precipitates were pumped separately through $1-\mu \mathrm{m}$ filters. The filters were dried, taped onto aluminum disks, and loaded into an Ortec Octete 8-channel alpha spectroscopy system at Brigham Young University for counting. Samples were counted for at least 2 weeks to allow enough data for a rigorous statistical analysis. A blank was also run to measure background. A conservative error for measured values was calculated using the approximation:

$1 \sigma$ counts error $=(\text { total counts })^{1 / 2}$

We tested this method by analyzing the Tridacna samples with well-constrained ages from East Timor (described in Cox, 2009). Tridacna sample Lau-16 has a predicted age of 118-128 ka based on coral U-Th ICP-MS ages from the uplifted terrace where it is found (Cox, 2009). Tridacna sample Com-18b was collected from a locality sandwiched between two corals with reliable U-series MC-ICP-MS ages of $6591 \pm 45$ and $7287 \pm 49$. The age of the Tridacna

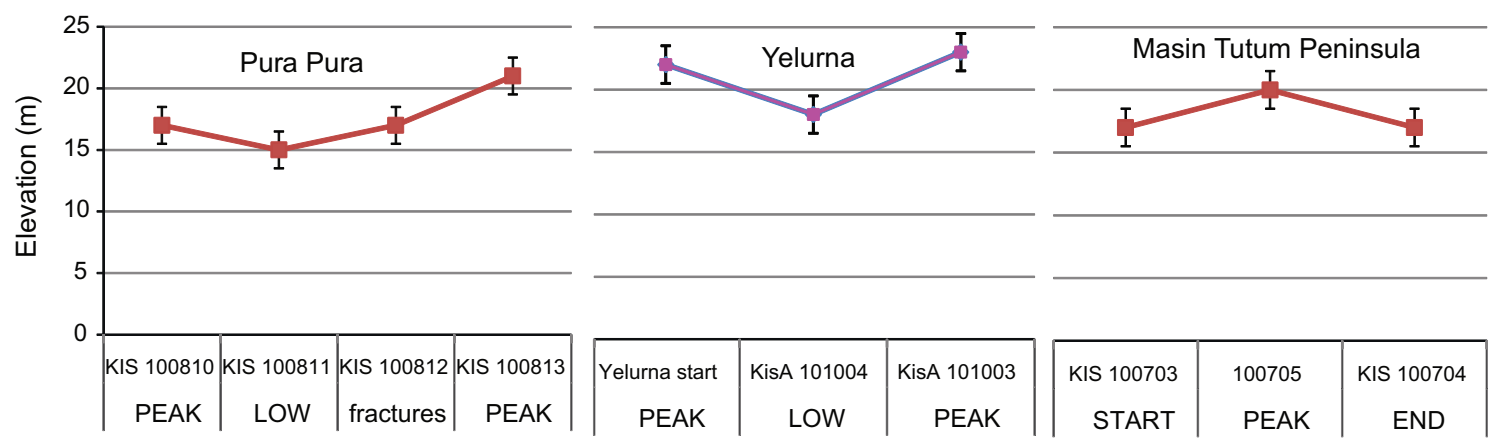

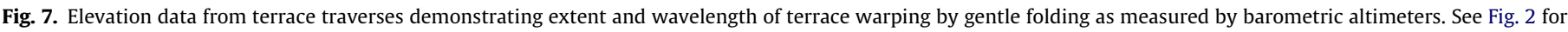
map locations. 
Table 2

U-series data for coral.

\begin{tabular}{|c|c|c|c|c|c|c|c|}
\hline ID & Location & Elevation $(\mathrm{m})$ & MIS STAGE & Age corrected & Error $(2 \sigma)$ & $\delta^{234} \mathrm{U}_{\text {initial }}$ corrected & Error $(2 \sigma)$ \\
\hline \multicolumn{8}{|c|}{ Coral data analyzed at NTU by MC-ICP-MS (simplified) } \\
\hline $\mathrm{JAB}-1$ & Jawalan, E coast, Kisar & 4 & $5 e$ & $127,682^{\mathrm{b}}$ & \pm 892 & 166.3 & \pm 3.9 \\
\hline JAB-2 & Jawalan, E coast, Kisar & 2 & $5 e$ & $123,067^{\mathrm{b}}$ & \pm 784 & 151.8 & \pm 3.2 \\
\hline KIS-A-1 & Oimara, NE coast, Kisar & 6 & $5 e$ & 121,198 & \pm 474 & 142.0 & \pm 2.3 \\
\hline KIS-A-2 & Oimara, NE coast, Kisar & 6 & $5 e$ & $121,774^{\mathrm{c}}$ & \pm 520 & 138.8 & \pm 2.5 \\
\hline KIS-B & Oimara, NE coast, Kisar & $19^{a}$ & - & 32.2 & \pm 5.1 & 149.4 & \pm 2.2 \\
\hline NAB-1 & Nama, W coast, Kisar & $8^{a}$ & - & 103.4 & \pm 5.3 & 145.3 & \pm 2.3 \\
\hline NAB-2 & Nama, W coast, Kisar & $20^{\mathrm{a}}$ & - & 104.2 & \pm 5.3 & 148.2 & \pm 2.7 \\
\hline OLT-01 & Olilit Timur, Samlauki, Yamdena & 1 & 1 & $5601^{\mathrm{c}}$ & \pm 23 & 127.7 & \pm 2.4 \\
\hline POL-1 & Portukil, N coast, Kisar & 6 & $\sim 5 \mathrm{c}$ & $108,648^{\mathrm{c}}$ & \pm 768 & 137.1 & \pm 3.9 \\
\hline PUL-1 & Pura Pura, E coast, Kisar & 3 & $5 e$ & $127,829^{b}$ & \pm 825 & 157.6 & \pm 3.7 \\
\hline PUL-2 & Pura Pura, E coast, Kisar & 1 & $\sim 5 \mathrm{e}$ & $131,208^{\mathrm{b}}$ & \pm 961 & 165.9 & \pm 3.9 \\
\hline UHU-1 & Nuhum, NE coast, Kisar & 3 & $5 e$ & $128,373^{\mathrm{b}}$ & \pm 1404 & 161.5 & \pm 5.0 \\
\hline YEN-1 & Yenihair, N coast, Kisar & 12 & $5 e$ & $126,660^{c}$ & \pm 902 & 169.9 & \pm 3.5 \\
\hline
\end{tabular}

Analytical errors are $2 \sigma$ of the mean.

Good, $\delta^{234} \mathrm{U}_{\text {initial }} 143-147 ; 2-3$ ppm U.

Estimated elevation error is $\pm 1 \mathrm{~m}$.

a Loose coral, not in place.

b Referable, $\delta^{234} U_{\text {initial }}$ slightly out of range.

${ }^{c}$ Unreliable, $\delta^{234} U_{\text {initial }}$ out of range.

sample from Kisar was expected to range from 100 ka to $550 \mathrm{ka}$ based on the best-fit correlation of terrace elevations and sea-level highstands.

Two independent methods also were utilized to verify U-series ages from alpha counting. The youngest Tridacna shell (Com-18b) was analyzed using the ${ }^{14} \mathrm{C}$ method. This ${ }^{14} \mathrm{C}$ age was determined by accelerator mass spectrometry (AMS) at the University of Georgia. A calibrated age was calculated using Calib 6.0 and the IntCal09 dataset (Reimer et al., 2009), and the total age was calculated by adding 2010 (analytical date), then subtracting 400 (generic reservoir correction for ocean bicarbonate) (see Appendix). As a second independent test, part of the Tridacna shell from Kisar (KIS 100405), assumed to be the oldest of the Tridacna samples, was sent for electron spin resonance (ESR) dating at the Research Laboratory for Quaternary Geochronology (RLQG) at the Institute of Geology, University of Technology, Tallinn, Estonia. Methods and background for ESR are described in Molodkov (1988) and Molodkov et al. (1998). Preliminary results showed the need for precise measurement of isotopic abundances in order to calculate a model age (A. Molodkov, pers. comm.), so a portion of the crushed sample was analyzed for U and Th isotopes by ICP sector field MS (ICP-SFMS) at ALS Environmental, Stockholm, Sweden.

\subsection{Results}

\subsubsection{Coral}

Only 4 of 13 coral samples analyzed by ICP-MS are considered "reliable" based on total U concentrations and a narrow range of acceptable $\delta^{234} U_{\text {initial }}$ (Table 2) values, but five other samples are considered "referable". The reliable samples show no isotopic evidence of alteration, as discussed in more detail in Cutler et al. (2003) and Edwards et al. (2003). The samples considered "referable" are due to their initial $\delta^{234} U$ being slightly out of expected range (146 $\pm 8 \%$ ), showing evidence for some alteration, but not enough to significantly affect the age, and four other samples are considered unreliable due to unacceptable ranges of initial $\delta^{234} \mathrm{U}$. These reliability criteria are the strictest possible in order to eliminate erroneous ages. However for the purpose of calculating longterm uplift rates from an entire flight of terraces, where nearly constant uplift at time scales of $10^{5}$ and $10^{6}$ years is likely, referable ages are also used.

Many studies worldwide show that high initial $\delta^{234} U$ ratios, especially in older fossil coral are the norm rather than the exception (e.g. Bar-Matthews et al., 1993; Bard et al., 1991; Chen et al., 1991; Dia et al., 1997; Stein et al., 1991). These studies discuss reasons for such elevated ratios, but admit it is difficult resolve. Early open-system behavior would yield apparently older ${ }^{230} \mathrm{Th}$ ages, whereas later alteration would decrease the apparent ${ }^{230} \mathrm{Th}$ age. Still, it is unlikely to be coincidental that in this study, even the most unreliable U-series ages, based on $\delta^{234} \mathrm{U}$, all fall within known highstands. Data from Cox (2009) shows similar difficulties in obtaining coral ages from the nearby north coast of East Timor.

All reliable or referable ages from in situ coral on Kisar fall within or very close to marine oxygen isotope stage (MIS) 5e, which occurred around $118-128 \mathrm{ka}$. This is a large, long-lived highstand on global sea-level curves (see Fig. 8). All three "fresh-looking" loose coral samples we found on higher weathered terraces yield very young ages (i.e. $<150$ years) and are discussed subsequently as evidence of possible tsunami deposits.

\subsubsection{Tridacna}

Tridacna shells from East Timor analyzed with alpha counting were close to their predicted ages, and the age obtained from the Tridacna shell from Kisar is within the predicted age range (Table 3 ). There was no measureable ${ }^{232} \mathrm{Th}$ peak in any of the spectra, showing zero detrital contamination in the samples and that essentially all Th measured is from in situ uranium decay. Neither $\mathrm{U}$ nor Th isotopes are at secular equilibrium, showing that they must be younger than $\sim 300 \mathrm{ka}$. Values of $\delta^{234} U_{\text {initial }}$ are somewhat near sea water (1.15) for two of the three samples, further strengthening the validity of the results.

The youngest Tridacna shell (Com-18b) yielded an age of 4100 years. This is different from the predicted age between 6591 and 7287 years based on MC-ICP-MS U-series ages of the enclosing corals, and an independent ${ }^{14} \mathrm{C}$ age by AMS on the shell of $6054 \pm 28(1 \sigma) \mathrm{yr}$. BP, which yields a calibrated age of 65426652 years (see Appendix). However, this discrepancy is no surprise considering its lower resolution and the difficulty in accurately measuring low abundances of ${ }^{230} \mathrm{Th}$ by alpha counting. The other, significantly older sample (Lau-16) from East Timor yields an age of $125,000 \pm 9100(1 \sigma)$, which falls within the already established age of the terrace where it was sampled (118-128 ka).

The U-series Tridacna shell age of $195 \pm 31$ ka from Kisar (sample KIS100405) is within $1 \sigma$ error of what was predicted and close to the MIS 7a highstand, which occurred at $\sim 200$ ka (Fig. 9), the sea 


\section{Stylized composite of Kisar terrace profiles based on $\mathrm{N} \& \mathrm{~W}$ coasts}

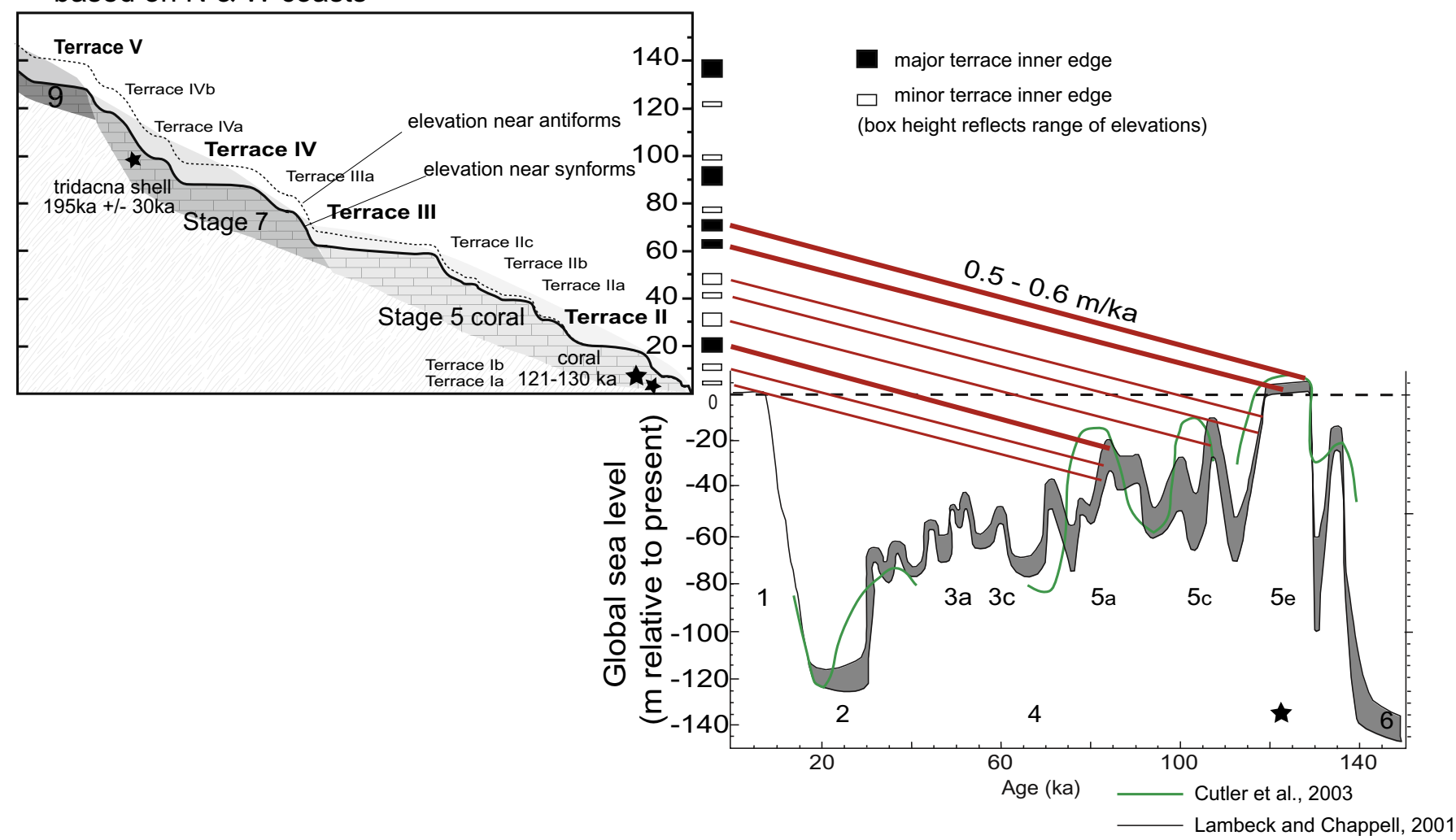

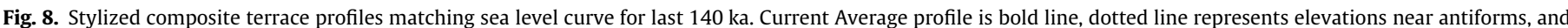

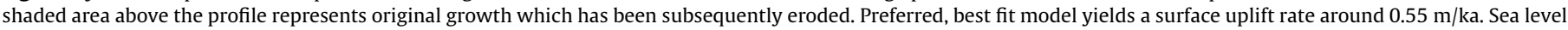
curves taken from Cutler et al. (2003) and Lambeck and Chappell (2001).

Table 3

Alpha counting U-series data for fossil tridacna shells.

\begin{tabular}{|c|c|c|c|c|c|c|c|c|c|c|}
\hline Location & Elevation & $\begin{array}{l}\text { Predicted age } \\
\text { (years) }\end{array}$ & $\begin{array}{l}\text { Calculated } \\
{ }^{230} \text { Th age }\end{array}$ & $1 \sigma \pm$ error & $\begin{array}{l}\text { Initial } \\
{ }^{234} U /{ }^{238} U\end{array}$ & $1 \sigma \pm$ error & $\begin{array}{l}\text { Activity } \\
{ }^{230} \mathrm{Th} /{ }^{238} \mathrm{U}\end{array}$ & $1 \sigma \pm$ error & $\begin{array}{l}\text { Activity } \\
{ }^{234} U /{ }^{238} U\end{array}$ & $1 \sigma \pm$ error \\
\hline \multicolumn{11}{|c|}{ Summary of alpha counting results on tridacna shells } \\
\hline Com, East Timor & $7 \mathrm{~m}$ & $6500-7000$ & 4100 & 2.5 & 1.1179 & 0.0002 & 0.0413 & 0.0288 & 1.1165 & 0.007 \\
\hline Lautem, East Timor & $60 \mathrm{~m}$ & $118,000-128,000$ & 125,100 & 9100 & 1.411 & 0.035 & 0.9121 & 1.6451 & 1.288 & 1.0899 \\
\hline Kisar & 95 m (Terrace IV) & 200,000 & 195,000 & 31,000 & 1.183 & 0.041 & 0.9412 & 2.5723 & 1.1051 & 1.2069 \\
\hline
\end{tabular}

Note: ${ }^{230} \mathrm{Th} /{ }^{232} \mathrm{Th}$ ratio not reported because no ${ }^{232} \mathrm{Th}$ peak was observed in spectra.

level rise leading to it, or possibly the preceding minor highstand. The large error in calculated U-series is a result of the low initial ${ }^{234} \mathrm{U} /{ }^{238} \mathrm{U}$ ratio and the lower precision of alpha counting method. Applying the ESR method on the same sample from Kisar produced a model age of $153.0 \pm 9.7 \mathrm{ka}$, and the isotopic data obtained by ICP-SFMS for that model age can also be used to calculate a U-Th age of $166 \mathrm{ka}$. Both these ages, based on different methods (and in the case of ESR, an entirely different physical principle), are also near, or within error, of the result obtained by alpha counting. These results indicate that the actual age of Tridacna shell must be significantly younger than the limits of the method of $\sim 300 \mathrm{kyr}$.

The fact that all shell analyses yield U-series ages close to independent age estimates is the strongest argument that the alpha counting method may be used to obtain low-resolution, referable ages from Tridacna shells if similar sampling and selection criteria are applied as for coral samples. As discussed in the previous section, initial $\delta^{234} U$ ratios in coral commonly show similar evidence of open-system behavior, although to a lesser degree. This discovery invites further testing of the method and greatly broadens the range of possibilities for determining ages of coral terraces along dry coastlines with good preservation of Tridacna shells (e.g. the southern Banda Arc).

\section{Discussion}

\subsection{Short-term surface uplift rates}

Terrace morphology and coral ages can be interpreted in several ways, and each yields a different surface uplift rate. The primary difficulty in interpreting these data is that all coral with reliable and referable ages are from the same marine oxygen isotope stage, have similar low elevations. Ideally, samples at higher elevations would always correspond to older ages, but a similar study of coral terraces in eastern Timor (Cox, 2009) shows that samples from the same terraces, only meters apart, have multiple ages corresponding to both sea-level highstands and glacial lowstands. Overlapping 
Stylized composite of Kisar terrace profiles based on $N \& W$ coasts

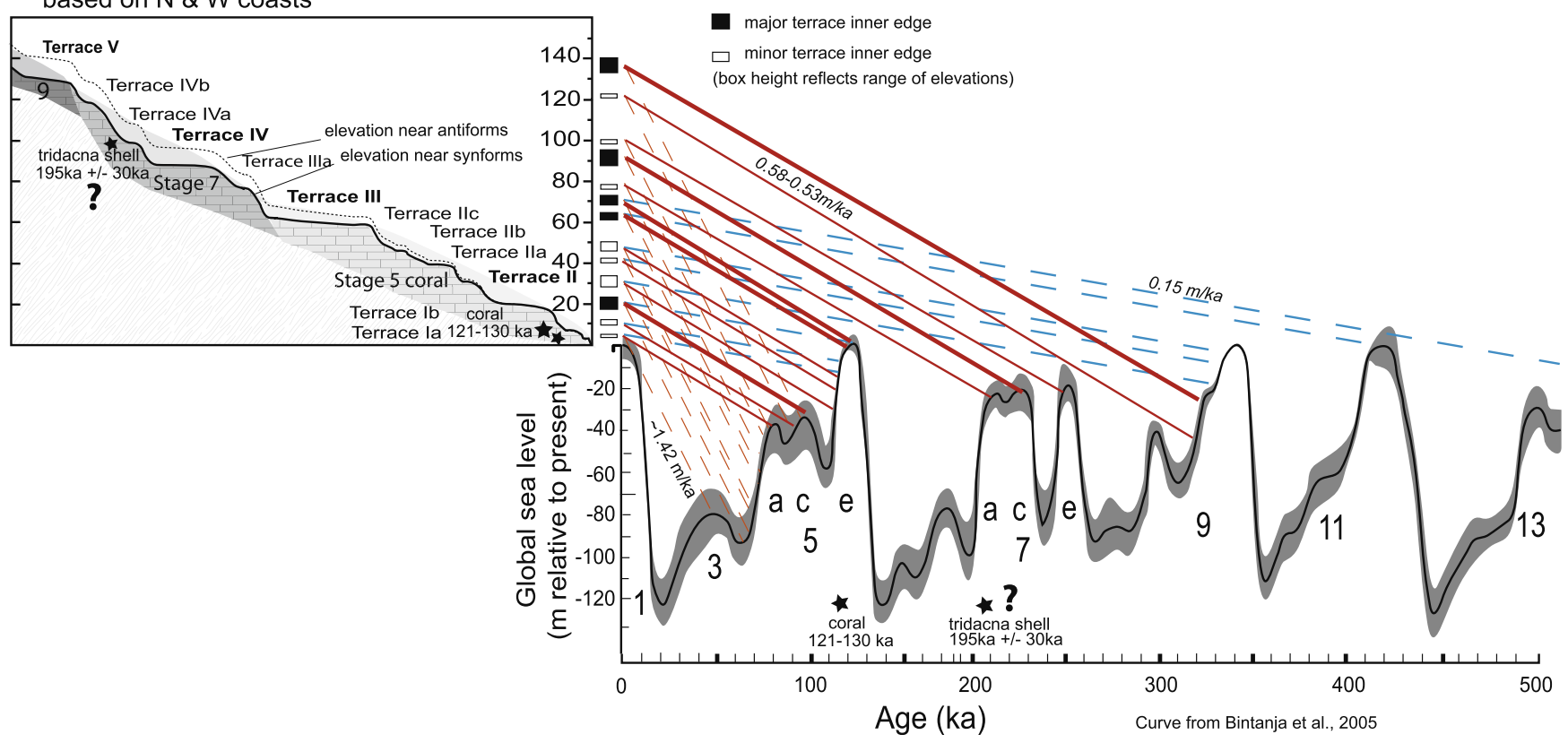

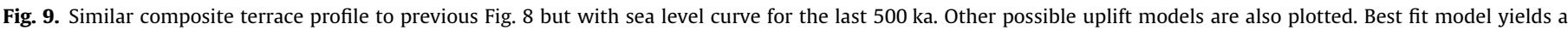

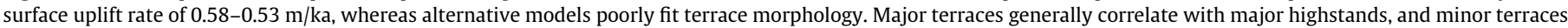
with minor highstands. Sea level curve from Bintanja et al. (2005).

ages are reported in other studies (e.g. Pirazzoli et al., 1991, 1993) and have been explained by polycyclic growth of new coral on older coral terraces.

These results raise questions about using direct calculations of surface uplift rate, which is given by using the highest dated coral sample, and assuming a growth depth of $2 \mathrm{~m}$ :

$\frac{6 \mathrm{~m}+2 \mathrm{~m}}{120,000 \mathrm{yr}}=0.000067 \mathrm{~m} / \mathrm{yr}=0.0667 \mathrm{~m} / \mathrm{ka}$

This rate should be considered as the lower limit, but is inconsistent with other observations, such as the total number of coral terraces and the age of a Tridacna shell.

A similar direct calculation of uplift using the U-series age of $\sim 200$ ka with corresponding paleo sea level ( $20 \mathrm{~m}$ below present), and the elevation of the dated Tridacna shell collected on terrace IV yields:

$\frac{95+20 \mathrm{~m}}{200,000 \mathrm{yrs}}=5.75 \times 10^{4} \mathrm{~m} / \mathrm{yr}=0.575 \mathrm{~m} / \mathrm{ka}$

Noting that there is also some considerable uncertainty about the age of the Tridacna shell, as discussed previously, the calculation corresponds to the maximum probable age and minimal difference in elevation between sea level at time of growth and present, which gives a minimum uplift rate. The directly calculated uplift rate is even higher if the actual age is younger because the change in paleo sea level to present is even greater for that time period.

The combination of coral and Tridacna age data from Kisar give geochronologic control at a set of elevations from 1 to $6 \mathrm{~m}$ and at $95 \mathrm{~m}$. The total level of uncertainty in the calculation is estimated at $\pm 5-10 \mathrm{~m}$ for paleo sea level, $\pm 3 \mathrm{~m}$ for coral growth depth, and $\pm 2 \mathrm{~m}$ for measured terrace elevation, the sum of which could vary the rate by $\sim 0.15 \mathrm{~m} / \mathrm{ka}$. The difference between the two direct calculations from different terraces is an order of magnitude, and could be interpreted to show that the assumption of a constant uplift is incorrect. However, these simple calculations of height over age do not take into account the complexity of the system, such as polycyclic coral growth and elevations from erosional terraces. An approach using all available data (e.g. geomorphology) is a more robust way to evaluate surface uplift.

\subsubsection{Geomorphology approach}

Estimating uplift rates in regions where many of the coral terraces are erosional, involves matching the observed elevations of terraces with those predicted by the record of sea level highstands, and using age data to test the best-fit model (Figs. 8 and 9). This approach assumes that uplift is more or less constant over hundreds of thousands of years, and provides a way to predict terrace ages where there is no direct age control. We accept the assumption of constant uplift is justified in the case of Kisar due to the likelihood that active thrust faults would have slip recurrence intervals on the order of hundreds of years at strain rates of $20 \mathrm{~mm} / \mathrm{yr}$, which is many times less than global sea level cyclicity. One advantage of this geomorphological method is that it does not rely entirely on age data alone, so questionable ages, such as the Tridacna shell do not necessarily effect the final result. Recognizing that most of the terraces are erosional, and that wide terraces correspond to major sea-level high stands can create a geochronologic framework against which uncertain ages be tested.

The best-fit uplift model for Kisar, using this geomorphological approach (Figs. 8 and Fig. 9), yields an uplift rate of $0.5-0.6 \mathrm{~m} / \mathrm{ka}$, which is similar to uplift rates found on neighboring East Timor and other islands in the region (Chappell and Veeh, 1978; Merritts et al., 1998; Scotney et al., 2005). The reasons we prefer this uplift rate is that it provides the closest correlation between: (1) the observed and predicted elevations of coral terraces, (2) major terraces and the major (longest-lasting highstands), or multiple closelyspaced highstands, (3) all coral and Tridacna shell ages with ages of major high-stands, and (4) minor high-stands and periods of rapid sea level fall to minor erosional terraces.

The MIS 5e ages of the lowest elevation terraces are explicable in terms of the fact that these terraces are erosional platform in 
nature, and not purely growth terraces. This observation implies that some erosional surfaces are younger than MIS 5e although the beveled coral itself yields a MIS 5e age. As sea level dropped after the MIS 5e, erosional terraces formed little, if any, new coral on the beveled terrace. The best-fit model also yields a similar uplift rate to the direct uplift calculation based on the age of the Tridacna shell.

Other possible uplift rates we tested are not viable. For example, a low-end hypothetical uplift rate of $0.15 \mathrm{~m} / \mathrm{ka}$, is not tenable because it would not produce the total number of terraces preserved (Fig. 9). The low rate implies that terrace II is the only one formed during the MIS 5e (118-128 ka) global sea-level highstand. Terraces Ia and Ib would have formed during the following regression in eustatic sea level, and the terraces of subsequent highstands would still be underwater. According to this model, MIS 7 would be completely overgrown by MIS stage 5 e. Coral terrace preservation is also difficult at such slow uplift rates, as a combination of erosion and growth would obscure older terraces.

A higher hypothetical uplift rate of $\sim 1.4 \mathrm{~m} / \mathrm{ka}$, which is found locally in eastern Timor (Cox, 2009), also correlates poorly with the predicted pattern (Fig. 9). At this rate the large wide terraces II, III, and IV would have formed during a rapid marine regression, along with all of their minor terraces. Also, the encrustation of the MIS stage 5e coral terrace would have to be over $200 \mathrm{~m}$ in elevation. The age of the Tridacna shell in growth position is also difficult to explain with this model.

\subsubsection{Summary}

Rapid uplift rates correspond to a greater number of terraces. In the case of Kisar and nearby Timor, most of the terraces are erosional in nature. Erosional terraces formed due to sea level changes during uplift at time scales of 100-200 ka. They are characterized by erosion of older coral reef. The beveled nature of these terraces makes direct age determinations difficult, because coral of the same age as the erosion is not very well preserved. Since the freshest samples of these terraces are typically found in incised valleys below the erosional surface, the ages of the corals usually represent an earlier sea level rise that was later carved into by a much younger sea level change. Recognizing the erosional nature of most terraces best explains why multiple terraces consist of similar aged coral, or why the same terrace can have coral samples of multiple ages.

Applying the best-fit uplift rate $(\sim 0.55 \mathrm{~m} / \mathrm{ka})$ to the topography of the island predicts that the highest elevation point $(\sim 240 \mathrm{~m})$ first emerged from the sea at around $450 \mathrm{ka}$. This makes it among the youngest emergent non-volcanic islands in the region. The peak that emerged to form the island of Kisar rises $3000 \mathrm{~m}$ above the present forearc basin floor. Assuming the same constant long-term uplift rate and that present basin depth has not changed, it would have taken the peak of Kisar 5-6 m. y. to rise from the basin floor to the surface. This assumption may also be supported by micropaleontology data from nearby Timor (Haig, 2012) which suggests that paleobathymetry in the Timor region nearest to Kisar at $5.5 \mathrm{Ma}$ was on the order of a $1.5-2.5 \mathrm{~km}$. The age of uplift is consistent with ${ }^{40} \mathrm{Ar} /{ }^{39} \mathrm{Ar}$ mica cooling ages of 5-6 Ma related to the timing of exhumation of the metamorphic rocks that of the Aileu Complex on neighboring Timor (Berry and McDougall, 1986), which are similar in composition and metamorphic grade to those on Kisar (Harris, 2011; Harris et al., 2000; Major, 2011). The exact timing of collision in Timor has been somewhat controversial, part of which can be attributed to the differences in the types of data that is available (Harris, 2011).

\subsection{Neotectonic deformation}

The emergence of Kisar cannot be explained by one exclusive mechanism. The overall pinnacle shape of Kisar and the $3 \mathrm{~km}$ depth of the surrounding basin floor it rises from are consistent with a localized uplift, such as a dome. Seismic data shows that forearc sediment thins towards Kisar (Jongsma et al., 1989), which implies syndepositional uplift during the Pliocene and Pleistocene.

However, systematic warping of the terraces into E-W trending folds indicates that uplift is also influenced by $\mathrm{N}-\mathrm{S}$ shortening. A north-verging thrust that breaks the surface of the sea floor is imaged in the BIRPS seismic reflection line located $15 \mathrm{~km}$ east of Kisar (Snyder et al., 1996), which we name the Kisar Thrust. A close examination of the seismic data (Fig. 11 in Snyder et al., 1996) shows two wavelengths of $\mathrm{E}-\mathrm{W}$ trending folds, one at the scale of Kisar itself, and shorter-wavelength folding within the thrust sheet at the same scale as terrace warping. The coastline of Kisar shows a series of what we interpret to be fold-related embayments and protrusions along a roughly square coastline consistent with this mechanism. Efforts to trace fold hinges through psammitic metamorphic rocks is frustrated by the multi-phase and shortwavelength nature of the deformation (see Major, 2011).

One of the geometrical inconsistencies of explaining all of the uplift by thrusting is the pinnacle shape of the Kisar uplift. Most thrust-related uplifts typically create arcuate, elongated ridges, such as is seen in most of the outer Banda Arc islands, versus isolated, circular protrusions like Kisar.

Another possible contributing mechanism for the uplift of the island is a buoyancy-driven, domal extrusion process, such as an emergent metamorphic dome. This hypothesis is consistent with the pinnacle shape of the uplift and the roughly equidimensional shape of Kisar. Yet, such a mechanism acting alone would likely result in a circular or ovoid shaped island. The square shape of Kisar may be explained by a combination of thrusting and domal extrusion mechanisms that may be jointly responsible for the island's emergence. For example, thrusting may have initiated domal rise of the meta-sedimentary rocks that make up Kisar.

The thrust fault and domal extrusion mechanisms are not mutually exclusive. Many well-documented metamorphic domes are associated with thrust faults and contractional ductile flow near suture zones (Whitney et al., 2004; Yin, 2004). The evidence for suturing of the Banda volcanic Arc to the Australian continental margin is well established in the region (Genrich et al., 1996; Hamilton, 1979; Price and Audley-Charles, 1987). The isolated uplift of Kisar also cannot be easily explained by lithospheric scale isostatic deformation associated with slab tear or delamination alone (Kaneko et al., 2007). Lithospheric processes act on too large of a scale to create such small $(<20 \mathrm{~km})$ and isolated feature as Kisar, and no similarly shaped islands exist in the Banda Arc besides those in the volcanic arc. Crustal shortening and domal extrusion processes remain the most likely uplift mechanism at the scale of $\operatorname{Kisar}(\sim 10 \mathrm{~km})$, especially where nearby an active thrust is imaged, cutting all of the way to seafloor (Snyder et al., 1996) and coral terraces are warped at fold wavelengths imaged above the thrust. There is an obvious regional uplift due to underthrusting of the Australian continental margin beneath the Banda forearc region (Harris, 2011). However, the warping of the coral terraces on Kisar and those in Timor (Harris, 2011) is best explained by short-wavelength processes.

\subsection{Paleotsunamis}

The loose coral found on top of terraces II (elevation 8-30 m) yield young ages of around 40 and 100 years (Table 2). There is no coral of this age anywhere on the island or any documented from nearby islands, which limits the source to the currently submerged seabed. These occurrences are not easily explained by human activity. It is possible that the scattered, large masses of coral were deposited by a tsunami of similar or younger age than the samples. A few other deposits of "fresh" coral were also observed 
on top of beveled terraces in several other locations on the island (Fig. 3). The most likely tsunamogenic faults in the region are the Timor Trough to the south, the Wetar Thrust to the north, and the Kisar Thrust beneath and extending east of the island. Dutch colonial records document several significant tsunamis in the eastern Indonesia region with wave run up heights of up to $15 \mathrm{~m}$ (Major et al., 2008).

\section{Conclusions}

This study provides the first coral ages and the first preliminary surface uplift rate and mechanism for the outer Banda Arc islands between Timor and Tanimbar. The uplifted coral terraces on Kisar record Quaternary surface uplift and neotectonic deformation of the island. Coral analyzed from the lower terraces of Kisar is entirely MIS 5e in age and combined with terrace profiles yield a best-fit surface uplift rate of $0.5-0.6 \mathrm{~m} / \mathrm{ka}$. We have also demonstrated that Tridacna shells can yield apparently referable U-series ages by the alpha counting method for large samples. These ages have the temporal resolution to identify major, widely spaced highstands and perhaps more recent $(<120 \mathrm{ka})$ minor highstands as well.

From data and conclusions in previous studies (Bard et al., 1996; Cox, 2009; Pirazzoli et al., 1991, 1993) and the data collected for this study, we conclude that most terraces are composite in nature, and consist of terraces eroded into coral of different ages.

The warped deformation pattern of the terraces is similar to the wavelength of thrust-related folds imaged just offshore and along strike from Kisar. However, the circular shape of the uplift, and the thinning of synorogenic deposits above it are much more consistent with domal extrusion activity. These Quaternary deformational features indicate that Kisar is still actively deforming and that measureable strain is taken up within the orogen by the Kisar Thrust. This thrust is associated with the northward movement of the orogenic wedge over the forearc basin. These structural and geomorphic features cannot be explained alone, if at all, by lithospheric scale uplift of the entire Timor region due to slab tear.

The discovery of young ( $\sim 100 \mathrm{yr}$ ), loose coral deposits on much older terraces above $8 \mathrm{~m}$ elevation are suggestive of paleotsunami deposits and would indicate that active faults in the Kisar region may be capable of producing tsunami with run-up heights that would destroy coastal settlements.

\section{Acknowledgements}

The authors would like to thank A.J. Barber and an anonymous reviewer for their comments which have improved our paper. Field work in Indonesia was aided by local field assistants Stenley Loupatty, Uchu, Emon, Agus, and Helen, Chamat and government officials, and the people of Kisar. The research was sponsored by UPN "Veteran" Yogyakarta, Indonesia, through the direction of the Dean of Fakultas Teknologi Mineral, Dr. Sari B. Kusumayudha. ESR dating was performed by Anatoly Molodkov at the Research Laboratory for Quaternary Geochronology (RLQG) at the Institute of Geology, University of Technology, Tallinn, Estonia.

This research was funded by NSF EAR 0337221 (to R.H.), grants from the BYU College of Physical and Mathematical Sciences (R.H.), the BYU Office of Research and Creative Activities (to J.M.), and a BYU Graduate Studies Research Fellowship (J.M.). Additional research funding came from the Horst \& Jessie von Bandat Memorial Grant awarded by the AAPG Foundation to J.M. U-series dating at the HISPEC was supported by the NSC Grants 99-2611-M-002006 and 99-2628-M-002-012 to CCS.

\section{Appendix A. Supplementary data}

Supplementary data associated with this article including sample locations, complete U-series, 14C, and ESR data, and a summary of terrace surveys can be found, in the online version, at http:// dx.doi.org/10.1016/j.jseaes.2013.04.023. These data also include Google maps locations of the most important areas described in this article.

\section{References}

Audley-Charles, M.G., 1986. Rates of Neogene and Quaternary tectonic movements in the Southern Banda Arc based on micropalaeontology. Journal of the Geological Society 143, 161-175.

Bard, E., Fairbanks, R.G., Hamelin, B., Zindler, A., Chi Track, H., 1991. Uranium-234 anomalies in corals older than 150,000 years. Geochimica et Cosmochimica Acta 55, 2385-2390.

Bard, E., Jouannic, C., Hamelin, B., Pirazzoli, P., Arnold, M., Faure, G., Sumosusastro, P., Syaefudin, 1996. Pleistocene sea levels and tectonic uplift based on dating of corals from Sumba Island, Indonesia. Geophysical Research Letters 23, 14731476.

Bar-Matthews, M., Wasserburg, G.J., Chen, J.H., 1993. Diagenesis of fossil coral skeletons: correlation between trace elements, textures, and ${ }^{234} \mathrm{U}^{238} \mathrm{U}$ Geochimica et Cosmochimica Acta 57, 257-276.

Berry, R.F., McDougall, I., 1986. Interpretation of ${ }^{40} \mathrm{Ar} /{ }^{39} \mathrm{Ar}$ and $\mathrm{K} / \mathrm{Ar}$ dating evidence from the Aileu Formation, East Timor, Indonesia. Chemical Geology; Isotope Geoscience Section 59, 43-58.

Bintanja, R., van de Wal, R.S.W., Oerlemans, J., 2005. Modelled atmospheric temperatures and global sea levels over the past million years. Nature 437, 125-128.

Bischoff, J.L., Fitzpatrick, J.A., 1991. U-series dating of impure carbonates: an isochron technique using total-sample dissolution. Geochimica et Cosmochimica Acta 55, 543-554.

Breen, N.A., Silver, E.A., Roof, S., 1989. The Wetar back arc thrust belt, eastern Indonesia; the effect of accretion against an irregularly shaped arc. Tectonics 8 , 85-98.

Brown, D., Huang, C.Y., 2009. An introduction to the Tectonophysics special issue on arc-continent collision processes. Tectonophysics 479, 1-3.

Carter, D.J., Audley-Charles, M.G., Barber, A.J., 1976. Stratigraphical analysis of island arc-continental margin collision in eastern Indonesia. Journal of the Geological Society 132, 179-198.

Chappell, J., Polach, H.A., 1972. Some effects of partial recrystallisation on ${ }^{14} \mathrm{C}$ dating Late Pleistocene corals and molluscs. Quaternary Research 2, 244-252.

Chappell, J., Veeh, H.H., 1978. Late Quaternary tectonic movements and sea-level changes at Timor and Atauro Island. Geological Society of America Bulletin 89, 356-368.

Charlton, T.R., Kaye, S.J., Samodra, H., Sardjono, 1991. Geology of the Kai Islands: implications for the evolution of the Aru Trough and Weber Basin, Banda Arc Indonesia. Marine and Petroleum Geology 8, 62-69.

Chen, J.H., Curran, H.A., White, B., Wasserberg, G.J., 1991. Precise chronology of the last interglacial period: ${ }^{234} \mathrm{U}-{ }^{230} \mathrm{Th}$ data from fossil coral reefs in the Bahamas. Geological Society of America Bulletin 103, 82-97.

Cheng, H., Edwards, R.L., Hoff, J., Gallup, C.D., Richards, D.A., Asmerom, Y., 2000. The half-lives of uranium-234 and thorium-230. Chemical Geology 169, 17-33.

Cox, N.L., 2009. Variable uplift from Quaternary folding along the northern coast of East Timor, based on U-series age determinations of coral terraces, Geological Sciences. Brigham Young University, Provo, p. 151.

Cox, N.L., Merritts, D., Harris, R., Chen, Y.-G., 2006. Quaternary uplift of coral terraces from active folding and thrusting along the northern coast of Timor-Leste. Abstracts with Programs - Geological Society of America 38, 509.

Cutler, K.B., Edwards, R.L., Taylor, F.W., Cheng, H., Adkins, J., Gallup, C.D., Cutler, P.M., Burr, G.S., Bloom, A.L., 2003. Rapid sea-level fall and deep-ocean temperature change since the last interglacial period. Earth and Planetary Science Letters 206, 253-271.

De Smet, M.E.M., Fortuin, A.R., Tjokrosapoetro, S., Van Hinte, J.E., 1989. Late cenozoic vertical movements of non-volcanic islands in the Banda Arc area. Netherlands Journal of Sea Research 24, 263-275.

Dia, A.N., Cohen, A.S., O’Nions, R.K., Jackson, J.A., 1997. Rates of uplift investigated through ${ }^{230}$ Th dating in the Gulf of Corinth (Greece). Chemical Geology 138 $171-184$.

Edwards, R.L., Chen, J.H., Wasserburg, G.J., $1987 .{ }^{238} \mathrm{U}-{ }^{234} \mathrm{U}-{ }^{230} \mathrm{Th}-{ }^{232} \mathrm{Th}$ systematics and the precise measurement of time over the past 500,000 years. Earth and Planetary Science Letters 81, 175-192.

Edwards, R.L., Gallup, C.D., Cheng, H., 2003. Uranium-series dating of marine and lacustrine carbonates. Reviews in Mineralogy and Geochemistry 52, 363-405.

England, P., Molnar, P., 1990. Surface uplift, uplift of rocks, and exhumation of rocks Geology 18, 1173-1177.

Fortuin, A.R., de Smet, M.E.M., 1991. Rates and Magnitudes of Late Cenozoic Vertical Movements in the Indonesian Banda Arc and the Distinction of Eustatic Effects. Blackwell Publishing Ltd.

Genrich, J.F., Bock, Y., McCaffrey, R., Calais, E., Stevens, C.W., Subarya, C., 1996 Accretion of the southern Banda arc to the Australian plate margin determined by global positioning system measurements. Tectonics 15, 288-295. 
Haig, D.W., 2012. Palaeobathymetric gradients across Timor during 5.7-3.3 Ma (latest Miocene-Pliocene) and implications for collision uplift. Palaeogeography, Palaeoclimatology, Palaeoecology 331-332, 50-59.

Hamilton, W.B., 1979. Tectonics of the Indonesian Region, U.S. Geological Survey Professional Paper. U.S. Geological Survey, Reston, VA, United States, United States.

Hantoro, W.S., Pirazzoli, P.A., Jouannic, C., Faure, H., Hoang, C.T., Radtke, U., Causse C., Best, M.B., Lafont, R., Bieda, S., Lambeck, K., 1994. Quaternary uplifted cora reef terraces on Alor Island, East Indonesia. Coral Reefs 13, 215-223.

Harris, R.A., 1991. Temporal distribution of strain in the active Banda orogen: a reconciliation of rival hypotheses. Journal of Southeast Asian Earth Sciences 6, 373-386

Harris, R.A., 1992. Peri-collisional extension and the formation of Oman-type ophiolites in the Banda arc and Brooks Range. Geological Society, London, Special Publications 60, 301-325.

Harris, R., 2006. Rise and fall of the Eastern Great Indonesian arc recorded by the assembly, dispersion and accretion of the Banda Terrane, Timor. Gondwana Research 10, 207-231.

Harris, R. 2011. The nature of the Banda Arc-continent collision in the timor region. In: Brown, D., Ryan, P.D. (Eds.), Arc-Continent Collision. Springer, Berlin, Heidelberg, pp. 163-211

Harris, R., Kaiser, J., Hurford, A., Carter, A., 2000. Thermal history of Australian passive margin cover sequences accreted to Timor during Late Neogene arccontinent collision, Indonesia. Journal of Asian Earth Sciences 18, 47-69.

Ishikawa, A., Kaneko, Y., Kadarusman, A., Ota, T., 2007. Multiple generations of forearc mafic-ultramafic rocks in the Timor-Tanimbar ophiolite, eastern Indonesia. Gondwana Research 11, 200-217.

Jongsma, D., Woodside, J.M., Huson, W., Suparka, S., Kadarisman, D., Stel, J.H., 1989 Geophysics and tentative late Cenozoic seismic stratigraphy of the Banda ArcAustralian continent collision zone along three transects. Netherlands Journal of Sea Research 24, 205-229.

Kadarusman, A., Maruyama, S., Kaneko, Y., Ota, T., Ishikawa, A., Sopaheluwakan, J., Omori, S., 2010. World's youngest blueschist belt from Leti Island in the nonvolcanic Banda outer arc of Eastern Indonesia. Gondwana Research 18, 189204.

Kaneko, Y., Maruyama, S., Kadarusman, A., Ota, T., Ishikawa, M., Tsujimori, T. Ishikawa, A., Okamoto, K., 2007. On-going orogeny in the outer-arc of the Timor-Tanimbar region, eastern Indonesia. Gondwana Research 11, 218-233.

Karig, D.E., Barber, A.J., Charlton, T.R., Klemperer, S., Hussong, D.M., 1987. Nature and distribution of deformation across the Banda Arc-Australian collision zone at Timor. Geological Society of America Bulletin 98, 18-32.

Kaufman, A., Broecker, W.S., Ku, T.L., Thurber, D.L., 1971. The status of U-series methods of mollusk dating. Geochimica et Cosmochimica Acta 35, 1155-1183.

Kuenen, P.H., 1942. Obilatoe, Kisar, and Siboetoe: contributions to the geology of the East Indies from the Snellius Expedition, Part II. Geologie en Mijnbouw (Netherlands Journal of Geosciences) 11-12, 81-90.

Lambeck, K., Chappell, J., 2001. Sea level change through the last glacial cycle. Science 292, 679-686.

Major, J.R., 2011. Pleistocene hinterland evolution of the active Banda arc: surface uplift and neotectonic deformation recorded by coral terraces at Kisar, Indonesia; and. Hinterland emergence of the active Banda arc-continent collision: metamorphism, geochronology, and structure of the uplifted Kisar Atoll, Indonesia and related rocks of Timor, Geological Sciences. Brigham Young University, pp. vii, 38, 63, 55 p.

Major, J.R., Harris, R.A., Robinson, J.S., 2008. Earthquake and Tsunami History and Hazards of Eastern Indonesia. Eos trans. AGU 89, Fall Meet. Suppl., Abstract T532009.

Masson, D.G., Milsom, J., Barber, A.J., Sikumbang, N., Dwiyanto, B., 1991. Recent tectonics around the island of Timor, eastern Indonesia. Marine and Petroleum Geology 8, 35-49.

McBride, J.H., Karig, D.E., 1987. Crustal structure of the outer Banda arc: new freeair gravity evidence. Tectonophysics 140, 265-273.

Merritts, D., Eby, R., Harris, R., Edwards, R.L., Chang, H., 1998. Variable rates of Late Quaternary surface uplift along the Banda Arc-Australian plate collision zone, eastern Indonesia. Geological Society, London, Special Publications 146, 213224

Molodkov, A., 1988. ESR dating of quaternary shells: recent advances. Quaternary Science Reviews 7, 477-484.

Molodkov, A., Dreimanis, A., Āboltinš, O., Raukas, A., 1998. The ESR age of Portlandia arctica shells from glacial deposits of Central Latvia: an answer to a controversy on the age and genesis of their enclosing sediments. Quaternary Science Reviews 17, 1077-1094.

Nugroho, H., Harris, R., Lestariya, A.W., Maruf, B., 2009. Plate boundary reorganization in the active Banda Arc-continent collision: insights from new GPS measurements. Tectonophysics 479, 52-65.

Omura, A., Konishi, K., Kakanishi, T., Sakanoue, M., 1973. Heterogeneities of uranium distribution in fossil and present-day Tridacna shells and their implications to dating. Japanese Journal of Geology and Geography (Science Council of Japan) Tokyo 43, 1-19.

Pirazzoli, P.A., Radtke, U., Hantoro, W.S., Jouannic, C., Hoang, C.T., Causse, C., Best, M.B., 1991. Quaternary raised coral-reef terraces on Sumba Island, Indonesia. Science 252, 1834-1836.

Pirazzoli, P.A., Radtke, U., Hantoro, W.S., Jouannic, C., Hoang, C.T., Causse, C., Best, M.B., 1993. A one million-year-long sequence of marine terraces on Sumba Island, Indonesia. Marine Geology 109, 221-236.

Price, N.J., Audley-Charles, M.G., 1987. Tectonic collision processes after plate rupture. Tectonophysics 140, 121-129.

Reimer, P.J., Baillie, M.G.L., Bard, E., Bayliss, A., Beck, J.W., Blackwell, P.G., Ramsey, C.B., Buck, C.E., Burr, G.S., Edwards, R.L., 2009. IntCal09 and Marine09 Radiocarbon Age Calibration Curves, 0-50,000 years cal BP.

Richardson, A.N., Blundell, D.J., 1996. Continental collision in the Banda arc Geological Society, London, Special Publications 106, 47-60.

Roosmawati, N., Harris, R., 2009. Surface uplift history of the incipient Banda arccontinent collision: geology and synorogenic foraminifera of Rote and Savu Islands, Indonesia. Tectonophysics 479, 95-110.

Sandiford, M., 2008. Seismic moment release during slab rupture beneath the Banda Sea. Geophysical Journal International 174, 659-671.

Scotney, P.M., Roberts, S., Herrington, R.J., Boyce, A.J., Burgess, R., 2005. The development of volcanic hosted massive sulfide and barite-gold orebodies on Wetar Island, Indonesia. Mineralium Deposita 40, 76-99.

Shen, C.-C., Edwards, R.L., Cheng, H., Dorale, J.A., Thomas, R.B., Bradley Moran, S., Weinstein, S.E., Edmonds, H.N., 2002. Uranium and thorium isotopic and concentration measurements by magnetic sector inductively coupled plasma mass spectrometry. Chemical Geology 185, 165-178.

Shen, C.-C., Cheng, H., Edwards, R.L., Moran, S.B., Edmonds, H.N., Hoff, J.A., Thomas, R.B., 2003. Measurement of attogram quantities of ${ }^{231} \mathrm{~Pa}$ in dissolved and particulate fractions of seawater by isotope dilution thermal ionization mass spectroscopy. Analytical Chemistry 75, 1075-1079.

Shen, C.-C., Kano, A., Hori, M., Lin, K., Chiu, T.-C., Burr, G.S., 2010. East Asian monsoon evolution and reconciliation of climate records from Japan and Greenland during the last deglaciation. Quaternary Science Reviews 29, 33273335.

Snyder, D.B., Prasetyo, H., Blundell, D.J., Pigram, C.J., Barber, A.J., Richardson, A., Tjokosaproetro, S., 1996. A dual doubly vergent orogen in the Banda Arc continent-arc collision zone as observed on deep seismic reflection profiles. Tectonics 15, 34-53.

Standley, C.E., Harris, R., 2009. Tectonic evolution of forearc nappes of the active Banda arc-continent collision: Origin, age, metamorphic history and structure of the Lolotoi Complex, East Timor. Tectonophysics 479, 66-94.

Stein, M., Wasserburg, G.J., Lajoie, K.R., Chen, J.H., 1991. U-series ages of solitary corals from the California coast by mass spectrometry. Geochimica et Cosmochimica Acta 55, 3709-3722.

Vita-Finzi, C., Hidayat, S., 1991. Holocene uplift in West Timor. Journal of Southeast Asian Earth Sciences 6, 387-393.

Whitney, D.L., Teyssier, C., Vanderhaeghe, O., 2004. Gneiss domes and crustal flow. Geological Society of America Special Papers 380, 15-33.

Yin, A., 2004. Gneiss domes and gneiss dome systems. Geological Society of America Special Papers 380, 1-14. 